Jurnal

Kardiologi Indonesia

J Kardiol Indones. 2014;35: 14-2 I

ISSN 0I26/3773

Clinical Research

\title{
Effect of Mitral Stenosis Severity on Blood Soluble Vascular Cell Adhesion Molecule-1 and Soluble Intercellular Adhesion Molecule-1 Levels
}

\author{
Pramono Sigit, Yoga Yuniadi, Indriwanto Sakidjan
}

Department of Cardiology and Vascular Medicine Faculty of Medicine Universitas Indonesia, and National Cardiovascular Center Harapan Kita, Jakarta-Indonesia
Background: Blood Soluble Vascular Cell Adhesion Molecule-I (sVCAM-I) and Soluble Intercellular Adhesion Molecule-I (sICAM-I) levels are increased in Mitral Stenosis (MS) patients, but whether this phenomenon is due to chronic rheumatic inflammation process or because of hemodynamic effect of mitral stenosis severity is not clear yet.

Objective: This research aims to study the effect of mitral stenosis severity on blood sVCAM-I and sICAM-I levels.

Method: This study is a cross sectional study. Research subjects were divided into 3 groups: control patients, pre BMV (Baloon Mitral Valvulotomy) group, and post BMV group (patients who have already undergone BMV for $\geq$ Iyear). Blood sVCAM-I and sICAM-I were measured using quantitative sandwich immunoassay method in all groups, and echocardiographic study to evaluate MS severity (MVA (Mitral Valve Area), mMVG (mean Mitral Valve gradient), TVG (Tricuspid Valve Gradient), mPAP (mean Pulmonary Artery Pressure), and LAVI (Left Atrial Volume Index) were performed to pre BMV and post BMV group at the same day with the blood sample collections.

Results: There were 23 normal subjects, 26 patients in pre BMV group, and 27 patients in post BMV group. The sVCAM- $I$ and sICAM-I levels in patients with MS (pre BMV and post BMV group) were higher than normal control subjects $(536,87 \pm 25 \mathrm{I}, 68 \mathrm{ng} / \mathrm{ml}$ vs $536,87 \pm \mathrm{I} 49,22 \mathrm{ng} / \mathrm{ml} ; \mathrm{p}<0,00 \mathrm{I}$ and $270,04 \pm 1 \mathrm{II}, 67 \mathrm{ng} / \mathrm{ml}$ vs $216,43 \pm 50,60 \mathrm{ng} / \mathrm{ml} ; \mathrm{p}=0,006)$, meanwhile there were no differences of SVCAM-I and sICAM-I levels between pre BMV and post BMV group $(854,67 \pm 227,26 \mathrm{ng} / \mathrm{ml}$ vs $809,22 \pm 275,63$ $\mathrm{ng} / \mathrm{ml} ; \mathrm{p}=0,5 \mathrm{I} 5$ dan $279,98 \pm \mathrm{II} 4,39 \mathrm{ng} / \mathrm{ml}$ vs $260,49 \pm \mathrm{II} 0,38 \mathrm{ng} /$ $\mathrm{ml} ; \mathrm{p}=0,539)$. There were also no significant correlation between mitral stenosis severity (MVA, mMVG, TVG, mPAP dan LAVI) with sVCAM- I and sICAM-I levels $(p>0,05)$.

Conclusion: There were no correlation between mitral stenosis severity with blood sVCAM-I and sICAM-I levels

(J Kardiol Indones. 20I4;35:I4-2I)

Keywords: sVCAM-I, sICAM-I, Mitral stenosis severity, MVA, BMV 
Jurnal

\title{
Pengaruh Tingkat Keparahan Stenosis Mitral Terhadap Kadar Soluble Vascular Cell Adhesion Molecule- 1 dan Soluble Intercellular Adhesion Molecule-1
}

\author{
Pramono Sigit, Yoga Yuniadi, Indriwanto Sakidjan
}

\begin{abstract}
Latar Belakang: Kadar Soluble Vascular Cell Adhesion Molecule-1 (sVCAM-1) dan Soluble Intercellular Adhesion Molecule-1 (sICAM-1) diketahui meningkat pada pasien dengan stenosis mitral (SM). Namun, apakah kenaikan tersebut disebabkan oleh proses reumatik yang aktif ataukah karena pengaruh hemodinamik SM masih belum diketahui dengan jelas.

Tujuan: Meneliti pengaruh tingkat keparahan SM pada kadar sVCAM-1 dan sICAM-1

Metode: Penelitian ini berdesain potong lintang. Subjek penelitian dibagi menjadi tiga kelompok, yaitu kelompok kontrol normal, kelompok pasien yang akan menjalani Komisurotomi Mitral Transvena Perkutan (kelompok pre KMTP), dan kelompok pasca KMTP $\geq 1$ tahun. Dilakukan pemeriksaan kadar sVCAM-1 dan sICAM-1 pada ketiga kelompok tersebut, dan pemeriksaan ekokardiografi untuk menilai tingkat keparahan katup mitral (Mitral Valve Area (MVA) mean Mitral Valve Gradient (mMVG), Tricuspid Valve Gradient (TVG), mean Pulmonary Artery Pressure (mPAP) dan Left Atrial Volume Index (LAVI)) pada kelompok pre KMTP dan kelompok pasca KMTP $\geq 1$ tahun.

Hasil: Didapatkan 23 orang kontrol normal, 26 pasien kelompok pre KMTP, dan 27 pasien kelompok pasca KMTP $\geq 1$ tahun.. Kadar sVCAM-1 dan sICAM-1 pada kelompok pasien dengan SM (kelompok pre dan pasca KMTP $\geq 1$ tahun) lebih tinggi dibandingkan dengan kontrol normal $(536,87 \pm 251,68 \mathrm{ng} / \mathrm{ml}$ vs 536,87 $\pm 149,22 \mathrm{ng} / \mathrm{ml} ; \mathrm{p}<0,001 \mathrm{dan} 270,04 \pm 111,67 \mathrm{ng} /$ $\mathrm{ml}$ vs $216,43 \pm 50,60 \mathrm{ng} / \mathrm{ml} ; \mathrm{p}=0,006)$. Namun tidak didapatkan perbedaan kadar sVCAM-1 dan sICAM-1 antara kelompok pre KMTP dengan kelompok pasca KMTP $\geq 1$ tahun $(854,67 \pm 227,26 \mathrm{ng} / \mathrm{ml}$ vs 809,22 $2275,63 \mathrm{ng} / \mathrm{ml} ; \mathrm{p}=0,515$ dan 279,98 $\pm 114,39 \mathrm{ng} / \mathrm{ml}$ vs $260,49 \pm 110,38 \mathrm{ng} / \mathrm{ml} ; \mathrm{p}=0,539)$. Tidak didapatkan hubungan antara tingkat keparahan katup mitral (MVA, mMVG, TVG, mPAP dan LAVI) dengan kadar sVCAM-1 dan sICAM-1 (p>0,05).

Kesimpulan: Tidak terdapat hubungan antar tingkat keparahan katup mitral dengan kadar kadar sVCAM-1 dan sICAM-1.
\end{abstract}

(J Kardiol Indones. 2014;35:14-21)

Kata Kunci: sVCAM-1, sICAM-1, Stenosis Mitral, tingkat keparahan, MVA, KMTP

\section{Latar Belakang}

\section{Alamat Korespondensi}

dr. Pramono Sigit, SpJP. Departemen Kardiologi dan Kedokteran Vaskular, Fakultas Kedokteran Universitas Indonesia, JakartaIndonesia, E-mail: yp.sigit@gmail.com

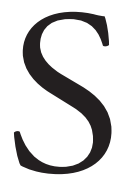

tenosis mitral (SM) merupakan penyakit yang masih sering dijumpai pada negaranegara berkembang. Etiologi terbanyak dari SM adalah penyakit jantung reumatik (lebih 
dari 90\% kasus). ${ }^{1-3}$ Pada dekade terakhir penelitian tentang biomarker pada SM mulai banyak dilakukan, diantaranya adalah tentang Vascular cell adhesion molecule-1 (VCAM-1) dan Intercellular adhesion molecule-1 (ICAM-1). . $^{-7}$

VCAM-1 dan ICAM-1 adalah glikoprotein permukaan yang berfungsi sebagai molekul adhesi yang berperan penting pada proses inflamasi demam reumatik. Kedua molekul tersebut memfasilitasi migrasi dan infiltrasi $\mathrm{CD}^{+}$dan $\mathrm{CD}^{+}$yang merupakan proses awal peradangan dan pembentukan jaringan parut pada katup pada demam reumatik. ${ }^{8}$ Penelitian yang dilakukan oleh Saikia et al. menunjukkan peningkatan ekspresi VCAM-1 dan ICAM-1 pada endothelium dan miokardium pasien dengan Penyakit Jantung Reumatik (PJR) Kronis. ${ }^{9}$ Sedangkan Yetkin et al. menemukan kenaikan kadar bentuk terlarut VCAM-1 dan ICAM-1, yaitu soluble VCAM-1 (sVCAM-1) dan soluble ICAM-1 (sICAM-1) pada pasien SM karena PJR dibandingkan dengan kontrol.4, ${ }^{6}$ Namun apakah kenaikan tersebut menunjukkan proses reumatik yang aktif atau merupakan akibat dari hemodinamik katup yang cedera masih belum diketahui dengan jelas. ${ }^{10}$

Hal ini penting untuk diketahui supaya biomarker tersebut dapat dimanfaatkan secara optimal pada pasien SM. Bila sVCAM-1 dan sICAM-1 berkaitan erat dengan inflamasi akibat proses reumatik kronis, maka kedua biomarker tersebut dapat digunakan pada uji klinis yang meneliti obat-obat yang bertujuan untuk menghambat proses inflamasi tersebut. ${ }^{11,12}$ Sedangkan bila sVCAM-1 dan sICAM-1 justru lebih berhubungan dengan perubahan hemodinamik SM daripada proses inflamasi maka kedua biomarker tersebut dapat menjadi penanda tingkat keparahan SM dan mungkin memiliki makna prognosis.

Chen et al. mencoba menjawab pertanyaan tersebut dengan mengukur kadar sVCAM-1 dan sICAM-1 pada 19 pasien SM yang akan menjalani Komisurotomi Mitral Transvena Perkutan (KMTP). Hasil penelitian menunjukkan kadar sVCAM-1 yang lebih tinggi dibanding kontrol normal namun tidak terdapat hubungan antara kadar sVCAM-1 dengan diameter atrium kiri, area atrium kiri, tekanan atrium kiri sebelum KMTP, dan luas area katup mitral. Di sisi lain kadar sVCAM-1 pasca KMTP menurun secara signifikan 1 minggu dan 4 minggu setelah KMTP. Chen et.al menyimpulkan bahwa kenaikan kadar sVCAM-1 merupakan hasil dari abnormalitas hemodinamik dan bukan karena aktivitas proses reumatik yang masih berlangsung. ${ }^{4}$ Pertanyaan mengenai kenapa kadar sVCAM-1 tidak berkorelasi dengan tingkat keparahan katup mitral sebelum KMTP sedangkan kadarnya menurun secara signifikan pasca KMTP masih belum terjawab.

Perbedaan hasil kadar sICAM-1 juga terdapat antara penelitian Yetkin et al. dan Chen et al. Tidak seperti penelitian Yetkin et al., Chen et al. tidak menemukan perbedaan kadar sICAM-1 antara kontrol normal dengan pasien SM. Terdapat beberapa kemungkinan penjelasan mengenai hal ini, namun pengaruh aspek metodologi pada hasil tersebut tidak dapat disingkirkan mengingat sampel pada penelitian Chen et al. hanya melibatkan 19 pasien SM. Berkaitan dengan hal tersebut, pada laporan penelitiannya Chen et al. juga menulis adanya kemungkinan terjadi kesalahan tipe II (type II error; kegagalan untuk menemukan adanya hubungan atau perbedaan antar variabel). ${ }^{4,13}$ Chen et al. sendiri menganggap bahwa penelitiannya masih merupakan penelitian pendahuluan dan penelitian lain masih dibutuhkan untuk mengkonfirmasi hasilhasil tersebut. ${ }^{4}$

\section{Metodologi}

Penelitian ini memiliki desain potong lintang. Pengambilan data dilakukan secara prospektif di Departemen Kardiologi dan Kedokteran Vaskular Fakultas Kedokteran Universitas Indonesia/Pusat Jantung Nasional Harapan Kita Jakarta, mulai Juni 2013 sampai November 2013. Subjek penelitian adalah pasien dengan SM signifikan akibat penyakit jantung reumatik yang merupakan kandidat untuk KMTP di Pusat Jantung Nasional Harapan Kita, Jakarta, serta pasien yang telah menjalani prosedur KMTP $\geq 1$ tahun yang lalu.

Kriteria inklusi untuk kelompok pre KMTP adalah SM signifikan (MVA $\leq 1,5 \mathrm{~cm} 2$ ) akibat proses reumatik dan memiliki karekteristik anatomis sesuai untuk KMTP (dijelaskan pada definisi operasional). Kriteria inklusi untuk kelompok pasca KMTP adalah pasien pasca KMTP $\geq 1$ tahun sebelum pengambilan sampel (ditetapkan sampai tanggal 15 November 2013). Kriteria inklusi untuk kelompok kontrol normal adalah individu sehat dan tidak memenuhi kriteria eksklusi. Kriteria eksklusi yang digunakan pada penelitian ini antara lain pasien tidak bersedia mengikuti penelitian; regurgitasi mitral derajat sedang atau lebih pasca KMTP; terdapat riwayat: keganasan, 
penyakit inflamasi, penyakit vaskular kolagen, penyakit hati atau ginjal, diabetes mellitus, hipertensi; riwayat demam reumatik akut dalam 6 bulan terakhir; riwayat endokarditis infektif atau infeksi bakterial lain yang memerlukan perawatan dalam 3 bulan terakhir; riwayat infeksi ringan dalam 1 minggu terakhir; dan riwayat trombosis vena dalam, emboli paru, atau operasi dalam 6 bulan terakhir

\section{Cara Kerja}

Subjek penelitian yang memenuhi kriteria dibagi menjadi 3 kelompok; yaitu pasien yang akan menjalani prosedur KMTP atau menjalani pemeriksaan TEE sebelum prosedur KMTP, pasien yang telah menjalani prosedur KMTP $\geq 1$ tahun yang lalu (diambil dari data Sistem Informasi Rumah Sakit RS Pusat Jantung Harapan Kita tahun 2008-2013), serta individu yang akan perlakukan sebagai kontrol normal. Usia dan jenis kelamin dari kontrol normal disesuaikan dengan karakteristik dari subjek penelitian pre dan pasca KMTP.

Setelah pengambilan informed consent dilakukan pencatatan data identitas dan karakteristik dasar subjek penelitian. Pemeriksaan ekokardiografi transtorakal untuk mengukur parameter echocardiografi yang meliputi: Mitral valve area (MVA), mean Mitral Valve Gradien (mMVG), Left Atrial Volume Index (LAVI), mean Pulmonary Artery Pressure (mPAP) dilakukan pada kelompok pre dan pasca KMTP.
Pengambilan darah dari vena perifer untuk pemeriksaan kadar sICAM-1 dan sVCAM-1 pada hari yang sama dengan pemeriksaan ekokardiografi pada ketiga kelompok. Warfarin sudah dihentikan 3 hari sebelum dilakukan pemeriksaan.

\section{Hasil Penelitian}

\section{Karakteristik Dasar Pasien SM dan Kontrol Normal}

Pengumpulan sampel penelitian dilakukan di RS Pusat Jantung Nasional Harapan Kita pada bulan Juni sampai bulan November tahun 2013. Diperoleh subjek penelitian sebanyak 76 orang yang terdiri dari 23 orang kontrol normal, dan 53 orang pasien SM (26 orang pasien yang akan menjalani prosedur KMTP dan 27 orang yang telah menjalani prosedur KMTP $\geq 1$ tahun yang lalu). Karakteristik dasar subjek penelitian dengan SM dan kontrol normal ditampilkan pada tabel 2.

\section{Perbandingan kadar sVCAM-I dan kadar sICAM-I antara kontrol normal dan pasien SM}

Kadar sVCAM-1 dan kadar sICAM-1 pada kontrol normal dan pasien SM (kelompok pre KMTP dan pasca KMTP $\geq 1$ tahun) ditampilkan pada tabel 2 .

Tabel 1. Karakteristik dasar pasien SM dan kontrol normal

\begin{tabular}{lccc}
\hline Variabel & $\begin{array}{c}\text { Kelompok Kontrol } \\
\text { Normal } \\
(\mathrm{n}=23)\end{array}$ & $\begin{array}{c}\text { Kelompok SM } \\
(\mathrm{n}=53)\end{array}$ & $\mathrm{p}$ \\
& $4104 \pm 7,65$ & $39,60 \pm 10,32$ & 0,550 \\
\hline Usai (tahun) & $91,3 \%$ & $90,6 \%$ & 0,644 \\
Jenis kelamin perempuan & $0 \%$ & $37,7 \%$ & $<0,001$ \\
Proporsi pasien dengan AF & &
\end{tabular}

Tabel 2. Perbandingan kadar sVCAM-1 dan slCAM-1 antara kontrol normal dan pasien SM

\begin{tabular}{lllll}
\hline & Kelompok & Rerata $(\mathrm{ng} / \mathrm{ml})$ & so(ng/ml) & $\mathrm{p}$ \\
\hline sVCAM-1 & Kontrol normal & 536,87 & 149,22 & $<0,001^{* *}$ \\
& SM & 831,52 & 251,68 & \\
si CAM-1 & Kontrol normal & 216,43 & 50,60 & $0,006^{* *}$ \\
& SM & 270,04 & 111,67 & \\
\hline${ }^{*}: \mathrm{p}<0,05,{ }^{* *}: \mathrm{p}<0,01$ & & & &
\end{tabular}


Tabel 3. Analisis multivariat pengaruh SM terhadap kadar sVCAM-1 dan s!CAM-1

\begin{tabular}{llccc}
\hline & Variabel & KoefiSien $\beta$ & $95 \% 1 \mathrm{~K}$ & $\mathrm{p}$ \\
\hline sVCAM-1 & MS & 270,09 & $142,56-397,61$ & $<0,001^{*}$ \\
& lrama AF & 66,80 & $-77,18-210,78$ & 0,358 \\
& Usia & 0,45 & $-5,70-6,60$ & 0,884 \\
& Jenis kelamin laki laki & $-13,39$ & $-195,31-168,52$ & 0,852 \\
\multirow{2}{*}{ siCAM-1 } & MS & 63,41 & $7,74-119,09$ & $0,026^{*}$ \\
& lrama AF & $-18,58$ & $-81,58-44,21$ & 0,555 \\
& Usia & 1,66 & $-1,00-4,31$ & 0,219 \\
& Jenis kelamin laki laki & $-61,40$ & $-143,22-20,21$ & 0,139 \\
\hline
\end{tabular}

${ }^{*}: \mathrm{p}<0,05,{ }^{* *}: \mathrm{p}<-0,01$

Tabel 4. Karakteristik Dasar Pasien SM pre KMTP dan Pasien SM pasc.a KMTP $\geq 1$ tahun

\begin{tabular}{lccc} 
Variabel & Kelompok 1: & Kelompok 2: & p \\
& Pre KMTP & Pasca KMTP $\geq 1$ tahun & \\
\hline & $(\mathrm{n}=26)$ & $(\mathrm{n}=27)$ & \\
Usia (tahun) & $38,501 \geq 11,39$ & $40,67 \pm 9,26$ & 0,599 \\
Jenis KelaminPerempuan & $92,3 \%$ & $88,9 \%$ & 0,907 \\
AF & $38,5 \%$ & $37,0 \%$ & 0,915 \\
MVA $\left(\mathrm{cm}^{\prime}\right)$ & $0,77 \pm 0,26$ & $1,34 \pm 0,28$ & $<0,001^{* *}$ \\
mMVG $(\mathrm{mmHg})$ & $13,58 \pm 5,40$ & $7,08 \pm 0,30$ & $<0,001^{* *}$ \\
LAVI $(\mathrm{ml} / \mathrm{ml})$ & $92,80 \pm 32,61$ & $66,11 \pm 23,87$ & $0,002^{* *}$ \\
TVG $(\mathrm{mmHg})$ & $62,67 \pm 33,45$ & $38,26 \pm 16,79$ & $0,003^{* *}$ \\
\hline m PAP $(\mathrm{mmHg})$ & $33,76 \pm 12,08$ & $22,33 \pm 8,36$ & $<0,001^{* *}$ \\
$*:$ p $<0,05^{* *}: \mathrm{p}<-0,01$ & & &
\end{tabular}

Tabel 5. Kadar sVCAM-1 dan sICAM-1 pada kelompok pre KMTP dan kelompok pasca KMTP $\geq 1$ tahun

\begin{tabular}{llccc}
\hline & Kelompok & Rerata $(\mathrm{ng} / \mathrm{ml})$ & SD $(\mathrm{ng} / \mathrm{m}) 1$ & $\mathrm{p}$ \\
\hline sVCAM-1 & pre KMTP & 854,67 & 227,26 & 0,515 \\
& pasca KMTP $\geq 1$ tahun & 809,22 & 275,63 & \\
\multirow{2}{*}{ siCAM-1 } & pre KMTP & 279,98 & 114,39 & 0,539 \\
& pasca KMTP $\geq 1$ tahun & 260,49 & 110,38 & \\
\hline
\end{tabular}

Tampak bahwa kadar sVCAM-1 dan sICAM-1 pada pasien SM lebih tinggi dari kontrol normal.

\section{Analisis Multivariat Pengaruh SM terhadap kadar SVCAM-I dan sICAM-I}

Analisis multivariat terhadap kadar sVCAM-1 dan sICAM-1 ditunjukkan pada tabel 3, tampak bahwa kadar sVCAM-1 dan sICAM-1 terutama ditentukan oleh ada tidaknya stenosis mitral, dan tidak tergantung dari irama AF, usia, maupun jenis kelamin.

\section{Karakteristik Dasar Pasien SM pre KMTP dan Pasien SM pasca KMTP $\geq$ I tahun}

Terdapat 26 orang pasien yang akan menjalani prosedur KMTP (kelompok pre KMTP), dan 27 orang yang telah menjalani prosedur KMTP $\geq 1$ tahun yang lalu (kelompok pasca KMTP $\geq 1$ tahun). Rerata waktu sejak KMTP sampai pemeriksaan ekokardiografi dan pengambilan sampel sVCAM-1 dan sICAM-1 pada kelompok pasca KMTP adalah 28,48 \pm 13,45 bulan. Karakteristik dasar dari masing-masing kelompok 
digambarkan pada tabel 4.

\section{Perbandingan kadar sVCAM-I dan kadar sICAM-I antara kelompok pre KMTP dan pasca KMTP $\geq$ I tahun}

Kadar sVCAM-1 dan kadar sICAM-1 pada kelompok pre KMTP dan kelompok pasca KMTP $\geq 1$ tahun ditampilkan pada tabel 5 . Tidak terdapat perbedaan kadar sVCAM-1 maupun sICAM-1 antara kelompok pasien pre KMTP dan kelompok pasien pasca KMTP $\geq 1$ tahun.

Hubungan antara tingkat keparahan SM dengan kadar sVCAM-I dan kadar sICAM-I

Hubungan antara tingkat keparahan SM dengan kadar sVCAM-1 dan sICAM-1 ditunjukkan pada tabel 6. Tampak bahwa tidak terdapat hubungan yang signifikan secara statistik antara MVA, mMVG, LAVI, TVG, maupun mPAP terhadap kadar sVCAM-1 dan sICAM-1.

\section{Pembahasan}

\section{Perbedaan Kadar sVCAM-I dan sICAM-I antara pasien SM dan Kontrol Normal}

Karakteristik dasar subjek penelitian menunjukkan bahwa sebagian besar pasien SM pada penelitian ini adalah perempuan $(90,57 \%)$. Hal ini sesuai dengan hasil pada penelitian-penelitian lain. ${ }^{4,6}$ Meskipun demikian masih belum ada penjelasan yang memadai mengenai peranan gender pada patofisiologi SM. ${ }^{14}$

Hasil penelitian menunjukkan bahwa kadar sVCAM-1 dan sICAM-1 pada kelompok pasien SM (pasien pre KMTP ditambah pasien pasca KMTP $\geq 1$ tahun) lebih tinggi dari kontrol normal $(p<0,001$ dan $\mathrm{p}=0,035)$. Temuan ini mengkonfirmasi temuan pada penelitian sebelumnya oleh Yetkin et al. namun berbeda kadarnya dengan penelitian tersebut. ${ }^{6}$ Kadar sVCAM-1 dan sICAM-1 kelompok kontrol normal pada penelitian ini adalah $536,87 \pm 149,22 \mathrm{ng} / \mathrm{ml}$ dan $270,04 \pm 124,18$ sedangkan pada penelitian Yetkin et al. sebesar $1,165 \pm 70 \mathrm{ng} / \mathrm{ml}$ dan $255 \pm 13 \mathrm{ng} / \mathrm{ml}$. Kadar sVCAM-1 dan sICAM-1 kelompok pre KMTP pada penelitian ini adalah $804,51 \pm 253,17 \mathrm{ng} / \mathrm{ml}$ dan $270,27 \pm 124,18 \mathrm{ng} / \mathrm{ml}$ sedangkan pada penelitian Yetkin et al. sebesar 4,630 $\pm 270 \mathrm{ng} / \mathrm{ml}$ dan 1,014 \pm $46 \mathrm{ng} / \mathrm{ml}^{6}$
Penelitian Chen et al. menemukan peningkatan kadar sVCAM-1 pada pasien SM dibandingkan dengan kontrol normal $(1,205.4 \pm 462.4 \mathrm{ng} / \mathrm{ml}$ vs $580 . \pm 208 \mathrm{ng} / \mathrm{ml}$; $\mathrm{p}<0,0001)$, namun tidak menemukan peningkatan yang bermakna secara statistik pada kadar sICAM-1 pasien SM dibanding kontrol normal $(772,6 \pm 305,8 \mathrm{ng} / \mathrm{ml}$ vs $670,8 \pm 103,7 \mathrm{ng} / \mathrm{ml} ; \mathrm{p}>0,05)$. Chen et al. berpendapat behwa kesalahan tipe II tidak dapat disingkirkan sebagai penyebab tidak ditemukannya peningkatan kadar sICAM-1 pada pasien SM tersebut. ${ }^{4}$

Perbedaan kadar sVCAM-1 dan sICAM-1 pada kontrol normal dan pasien pre KMTP pada penelitian ini dibanding kadar yang ditemukan pada penelitian Yetkin et al. dan Chen et al. mungkin disebabkan karena perbedaan reagen yang digunakan (pada penelitian ini digunakan reagen dari R\&D Systems Inc., $U S A$; penelitian Yetkin et al. menggunakan reagen Bender Med Systems, Vienna, Austria; penelitian Chen et al. menggunakan reagen Diaclone; Besancon; France) perbedaan usia (pada penelitian ini rerata usia 39,6 \pm 10,32 tahun; pada penelitian Yetkin et al. $34 \pm 5$ tahun, pada penelitian Chen et al. 56,2 $\pm 11,3$ tahun, serta perbedaan proporsi pasien dengan $\mathrm{AF}$ (pada penelitian ini 37,7\%; pada penelitian Chen et al. 35,3\%, pada penelitian Yetkin et al. tidak disebutkan). ${ }^{4,6}$ Meskipun demikian pada penelitian ini analisis multivariat tidak menemukan pengaruh usia dan irama AF terhadap kadar sVCAM-1 dan sICAM-1.

\section{Pengaruh Tingkat Keparahan SM terhadap Kadar sVCAM-I dan sICAM-I}

Tidak terdapat perbedaan karakteristik dasar yang bermakna dalam hal usia, jenis kelamin dan proporsi pasien dengan AF antara kelompok pre KMTP dan kelompok pasca KMTP $\geq 1$ tahun oleh karena itu kedua kelompok dapat dianggap setara dan dapat dilakukan perbandingan kadar sVCAM-1 dan sICAM-1 antar kedua kelompok tersebut.

Chen et al. menemukan penurunan kadar sVCAM-1 yang bermakna secara statistik pada pasien SM setelah 1 minggu $(1205,4 \pm 462,4 \mathrm{ng} / \mathrm{ml}$ menjadi $915,7 \pm$ $280,2 \mathrm{ng} / \mathrm{ml})$ dan 4 minggu pasca KMTP $(859,0 \pm 298,7$ $\mathrm{ng} / \mathrm{ml} ; \mathrm{p}<0,0001) .{ }^{4}$ Oleh karena itu diharapkan pada jangka waktu yang lebih lama akan terjadi penurunan lebih lanjut akibat perbaikan profil hemodinamik pasca KMTP yang terjadi secara gradual. Namun pada penelitian ini tidak ditemukan penurunan kadar sVCAM-1 pada pasien yang telah menjalani KMTP $\geq 1$ tahun meskipun data ekokardiografi menunjukkan 
parameter hemodinamik yang lebih baik pada kelompok pasien tersebut dibandingkan dengan kelompok pasien pre KMTP.

Sesuai dengan temuan tersebut, tidak ditemukan pula hubungan yang bermakna secara statistik antara tingkat keparahan SM yang diukur dengan parameter ekokardiografi (MVA, mMVG, TVG, mPAP, LAVI) dengan kadar sVCAM-1 ( $>>0,05)$.

Hasil penelitian yang didapatkan pada penelitian ini berbeda dengan penelitian Chen et al yang menemukan adanya perbedaan kadar sVCAM-1 pasca KMTP. Perbedaan antara hasil penelitian ini dan penelitian Chen et al. mungkin disebabkan oleh perbedaan populasi penelitian ini dengan populasi penelitian Chen dkk. (populasi penelitian di Taiwan dengan keadaan sosial ekonomi yang lebih baik). Pada penelitian ini umur pasien SM lebih muda daripada pada penelitian Chen et al. (39,6 $\pm 10,32$ tahun vs 56,2 $\pm 11,3$ tahun) dengan umur pasien termuda 14 tahun (termasuk Juvenile Mitral Stenosis karena usia < 20 tahun); hal tersebut mencerminkan tingkat infeksi Streptokokus $\beta$-Hemolitikus grup A yang lebih sering, serta tingkat serangan demam reumatik dan rekurensinya yang lebih sering. ${ }^{1,15-17}$ Terdapat kemungkinan terjadi infeksi ulang Streptokokus $\beta$-Hemolitikus grup A pada jangka waktu antara tindakan KMTP dengan saat pengukuran sVCAM-1 dan sICAM-1 yang menimbulkan peningkatan inflamasi karena proses reumatik. Selain itu pengaruh perbedaan desain penelitian antara penelitian ini (desain potong lintang) dengan penelitian Chen et al. (desain Kohort) terhadap perbedaan hasil penelitian juga tidak dapat disingkirkan. ${ }^{4}$

Pada penelitian ini tidak ditemukan perbedaan kadar sICAM-1 antara kelompok pasien pasca KMTP $\geq 1$ tahun dengan kelompok pasien pre KMTP, dan tidak ditemukan hubungan antara tingkat keparahan SM yang diukur dengan parameter ekokardiografi (MVA, mMVG, TVG, mPAP, LAVI) dengan kadar sICAM-1. Hasil ini sesuai dengan penelitian Chen et al. yang tidak menemukan penurunan yang bermakna dari kadar sICAM-1 pasca KMTP. ${ }^{4}$

Hasil-hasil penelitian ini mendukung teori bahwa kenaikan kadar sVCAM-1 dan sICAM-1 pada pasien SM lebih ditentukan oleh inflamasi kronis akibat proses reumatik kronis dan bukan akibat faktor hemodinamik SM.

\section{Keterbatasan Penelitian}

Penelitian ini tidak dapat mengikuti kadar sVCAM-1 dan sICAM-1 pasca KMTP secara serial pada pasien yang sama (desain kohort) karena keterbatasan waktu penelitian. Selain itu penelitian ini tidak memiliki data ada tidaknya infeksi Streptokokus $\beta$-Hemolitikus grup A selama masa sejak KMTP sampai pengukuran kadar sVCAM-1 dan sICAM-1.

\section{Kesimpulan}

Kadar sVCAM-1 dan sICAM-1 pada pasien SM moderate sampai severe lebih tinggi daripada kadar sVCAM-1 dan sICAM-1 pada kontrol normal. Tidak terdapat perbedaan kadar sVCAM-1 dan sICAM-1 antara pasien pasca KMTP $\geq 1$ tahun dengan pasien pre KMTP pada populasi pasien dengan SM moderate sampai severe. Tingkat keparahan pada SM moderate sampai severe tidak berhubungan dengan kadar sVCAM-1 dan sICAM-1.

\section{Saran}

Penelitian yang mengukur kadar sVCAM-1 dan sICAM-1 secara serial pasca KMTP menggunakan desain kohort dengan perhatian khusus pada ada tidaknya infeksi ulangan streptokokus beta hemolitikus grup A selama periode penelitian diperlukan untuk mengkonfirmasi hasil penelitian ini.

\section{Daftar Pustaka}

1. Chandrashekhar Y, Westaby S, Narula J. Mitral stenosis. Lancet. 2009 Oct 10;374(9697):1271-83. PubMed PMID: 19747723.

2. Kuncoro AS. Pemeriksaan Stenosis Mitral Akibat Proses Rheumatik Dengan Ekokardiografi. Jurnal Kardiologi Indonesi. 2010;31(1):62-5.

3. Yusak M. Stenosis mitral In: Rilantono LI, Baraas F, Karo SK, Roebiono PS, editors. Buku Ajar Kardiologi. 1 ed. Jakarta: Balai Penerbit Fakultas Kedokteran Universitas Indonesia; 2003. p. 135-44.

4. Chen MC, Chang HW, Juang SS, Yip HK, Wu CJ, Yu TH, et al. Percutaneous transluminal mitral valvuloplasty reduces circulating vascular cell adhesion molecule-1 in rheumatic mitral stenosis. Chest. 2004 Apr;125(4):1213-7.

5. Chen MC, Wu CJ, Yip HK, Chang HW, Fang CY, Yu TH, et al. Left atrial platelet activity with rheumatic mitral stenosis: correlation study of severity and platelet P-selectin expression 


\section{Sigit P dkk:Pengaruh tingkat keparahan stenosis mitral terhadap kadar sVCAM-I dan sICAM-I}

by flow cytometry. Chest. 2003 Nov;124(5):1663-9..

6. Yetkin E, Erbay AR, Ileri M, Turhan H, Balci M, Cehreli S, et al. Levels of circulating adhesion molecules in rheumatic mitral stenosis. The American journal of cardiology. $2001 \mathrm{Nov}$ 15;88(10):1209-11.

7. Yetkin E, Erbay AR, Turhan H, Balci M, Yetkin F, Yetkin G, et al. Changes in plasma levels of adhesion molecules after percutaneous mitral balloon valvuloplasty. Cardiovasc Pathol. 2004 Mar-Apr;13(2):103-8.

8. Roberts S, Kosanke S, Terrence Dunn S, Jankelow D, Duran CM, Cunningham MW. Pathogenic mechanisms in rheumatic carditis: focus on valvular endothelium. J Infect Dis. $2001 \mathrm{Feb}$ 1;183(3):507-11.

9. Saikia UN, Kumar RM, Pandian VK, Gupta S, Dhaliwal RS, Talwar KK. Adhesion molecule expression and ventricular remodeling in chronic rheumatic heart disease: a cause or effect in the disease progression--a pilot study. Cardiovasc Pathol. 2012 Mar-Apr;21(2):83-8.

10. Carabello BA. Modern management of mitral stenosis. Circulation. 2005 Jul 19;112(3):432-7.

11. Fadhilah A, Rahajoe AU, Kasim M. Atorvastatin Memodulasi Ekspresi Gen Tumor Necrosis Factor- $\alpha$, Interferon- $\gamma$ dan Interleukin-4 Pada Jaringan Katup dan Appendiks Atrium Kiri Penderita Penyakit Jantung Reumatik Jakarta: Universitas Indonesia; 2013.
12. Antonini-Canterin F, Hirsu M, Popescu BA, Leiballi E, Piazza R, Pavan D, et al. Stage-related effect of statin treatment on the progression of aortic valve sclerosis and stenosis. Am J Cardiol. 2008 Sep 15;102(6):738-42.

13. Dahlan MS. Kesalahan Tipe I, TIpe II, Power, dan Hipotesis Penelitian. Besar sampel dan cara pengambilan sampel dalam Penelitian Kedokteran dan Kesehatan. Jakarta: Salemba Medika; 2013. p. 24-33.

14. Movahed MR, Ahmadi-Kashani M, Kasravi B, Saito Y. Increased prevalence of mitral stenosis in women. Journal of the American Society of Echocardiography : official publication of the American Society of Echocardiography. 2006 Jul;19(7):911-3.

15. Shrivastava S, Dev V, Vasan RS, Das GS, Rajani M. Percutaneous balloon mitral valvuloplasty in juvenile rheumatic mitral stenosis. The American journal of cardiology. 1991 Apr 15;67(9):892-4.

16. Ahmad S, Hayat U, Naz H. Frequency of severe mitral stenosis in young female patients having pure mitral stenosis secondary to rheumatic heart disease. Journal of Ayub Medical College, Abbottabad : JAMC. 2010 Oct-Dec;22(4):19-22.

17. Bisno A, Butchart EG, Ganguly N, Ghebrehiwet T, Lue H-C, Kaplan EL, et al. Epidemiology of group A streptococci, rheumatic fever and rheumatic heart disease in WHO Expert Consultation on Rheumatic Fever and Rheumatic Heart Disease. Geneva: WHO, 2001 Contract No.: 923. 